\title{
Reinhold Niebuhr and Christian Realism, A Theology of Avarice
}

\section{Noah Pardell}

This paper takes a historical approach to describing theologian Reinhold Niebuhr's concept of Christian Realism, and its consequences for political thought in America. In the aftermath of World War I many people in America, especially Protestant clergy, became disillusioned with the idea of political intervention, focussing on domestic rather than international disputes. However, as National Socialism gained a foothold in Germany, culminating in the Second World War, the Protestant theology of Social Gospel Liberalism that gained popularity in the 1920's would not suffice for explaining the conduct of the Nazi party, nor the political action that America should take towards it. Niebuhr's Christian Realism, emphasizing the inevitability of sin in individuals and social institutions alike, provided a philosophy that emphasized action towards this political power, influencing American conduct and discourse as the war broke out across the Atlantic at the turn of the decade. 
Reinhold Niebuhr's Christian Realism was a theology forged in the inter-war period following the First World War. The unparalleled destruction observed in the Great War led many people in America, especially Protestant clergy, to adopt more isolationist, pacifist and antiinterventionist political stances. ${ }^{1}$ The horrors of WWI as well as the Great Depression of the 1930's influenced many Americans to spend their efforts dealing with domestic challenges, and to ignore the events of unrest happening in external nations. ${ }^{2}$ Such an event would come to be the rise of National Socialism, emerging partially as a result of the displeasure Germans had with the stipulations of the Treaty of Versailles. ${ }^{3}$ The Liberal Protestant standpoint, with its roots in the last decade of the $19^{\text {th }}$ century, continued into the 1920's and 30's and was advocated for by Christian Americans as an acceptable ethic for achieving positive social change within America. These changes could occur with many societal interactions, such as with class or racial relations. ${ }^{4}$ Liberal Protestantism and its Social Gospel movement championed by Walter Rauschenbusch regarded the ethic of absolute love preached by Jesus during the Sermon on the Mount to be pragmatic. ${ }^{5}$ Drawing on humanistic thought that came to fruition during the Renaissance, Protestant Liberals believed that as people transform their personal lives by readily embodying self-sacrificial love in daily and public discourse, life in America and around the globe could approach a form of utopia. ${ }^{6}$ By incorporating Jesus' tenet of unconditional love and altruistic action into every believer's personal life, social progress at the level of institutions and even nations would result. ${ }^{7}$ For example, the remedying of societal injustices such as the closure of the economic gap between workers and employers would become a "simple, historical possibility." 8 However, the world was approaching another phase of total war, and Nazi totalitarianism replete with its suppression of human rights and deification of the Führer came to the fore. America needed a theology that, unlike the Social Gospel, could interpret and make sense of the ideological fervour that would result in the calamity known as the Second World War.

Reinhold Niebuhr, a professor of Applied Christianity at Union Theological Seminary in New York starting in $1928^{9}$ was to provide a rebuttal and critique of Social Gospel Liberalism with its emphasis on inevitable social progress. This would manifest itself as a unique theology known today as Christian Realism. This theological explanation of political tension and conflict perpetrated by groups in positions of power was derived from a biblical understanding of human nature. ${ }^{10}$ Throughout the 1930 's Niebuhr would develop his theology, which would come to

\footnotetext{
'Justus D. Doenecke, "Reinhold Niebuhr and His Critics: The Interventionist Controversy in World War II," Anglican and Episcopal History 64, no. 4 (1995): 459; William C. Inboden, "The Prophetic Conflict: Reinhold Niebuhr, Christian Realism, and World War II," Diplomatic History 38, no. 1 (2014): 49-53.

Ibid., 49.

Ibid., 60 .

${ }^{4}$ Robin W. Lovin, Reinhold Niebuhr (Nashville: Abingdon Press, 2007), 2-3.

${ }^{5}$ Matt. 22:39

'Ibid., 2-8; Keith Pavlischek, "Reinhold Niebuhr, Christian Realism, and Just War Theory A Critique," in Christianity and Power Politics Today: Christian Realism and Contemporary

Political Dilemmas, ed. Eric Patterson (New York: Palgrave Macmillan US, 2008), 55-57; Doenecke, "Reinhold Niebuhr and His Critics," 460-61; Inboden, "The Prophetic Conflict," 5860 .

Lovin, Reinhold Niebuhr, 24; Pavlischek, "Just War Theory," 58.

${ }^{8}$ Lovin, Reinhold Niebuhr, 7.

' Ibid., 2.

"Ibid., 12-13.
} 
influence other theologians, political activists, and even President Roosevelt himself. ${ }^{11}$ Christian Realism would sway American dispositions from anti-interventionism to interventionism, from a theology grounded in the belief of inherent human goodness and social progression to a conviction of man's inescapable sinfulness.

The present discussion will illustrate Niebuhr's Christian Realism, from his conception of human nature through to how that nature is manifested in social and political institutions. In doing so it will become pertinent to highlight Christian Realism's views on how moral choices should be decided amongst people, and by extension nations, in a world fraught with sin and self-interest. Niebuhr's ideas were met with contention by proponents of pacifism such as theologian Georgia Harkness, as well as professors Robert Moats Miller and George H. C. Macgregor. Reinhold Niebuhr became one of the most influential theologians of the modern era, ${ }^{12}$ and the idolatrous Nazi Germany came to exemplify the very concepts proposed by him.

Niebuhr's understanding of human nature draws on a biblical interpretation, and provided the basic framework for Christian Realism. According to scripture, man is created in the image of God. ${ }^{13}$ Much like how God transcends all of creation and is therefore in possession of a freedom that cannot be apprehended by man, man transcends all other creatures and countenances a freedom that is unchallenged amongst other earthly life. This human freedom is understood as consciousness, rationality, and imagination, which provides the ability to contemplate our current situation and how that situation might be different. However, human freedom is finite and not absolute like God's, for it is still subject to natural forces and "tied to biological life." This means that human reasoning and the actions derived as a result are subject to the desires and follies of mortal life. ${ }^{14}$ This biblical conception of human nature provides a springboard for Niebuhr's theology. Drawing on the ideas of St. Augustine near the end of the $4^{\text {th }}$ century and into the $5^{\text {th }}$, as well as Søren Kierkegaard of the $19^{\text {th }}$, Niebuhr purports that man's freedom (or the awareness of our present situation and the knowledge that circumstances could have been different) elicits anxiety. The flux between corporeal desires and the worry that such desires, once attained, might be lost is natural human impulse. ${ }^{15} \mathrm{Sin}$ is the response to such anxiety, which Niebuhr deems 'Pride'. Other individuals (or in the case of international affairs, nations) become competitors and are viewed as threats. The individual/nation then utilizes power and force to maintain control of their situation, and ensure security for themselves. "When humans become aware of their limitations," the use of force and therefore sin inevitably results. ${ }^{16}$ In sum, Niebuhr "emphasized the mixed and ambivalent nature of human nature - creative impulses matched by destructive impulses, [and] regard for others overruled by excessive selfregard [and] the will to power." "17 The idea that human sin arises from our response to anxiety caused by our own finitude is key to Christian Realism. Given this theorem that sin permeates through every individual, it is concluded that every humanly constructed body whether social or political is affected as well. Before discussing how Christian Realists regarded moral choices in

"Inboden, "The Prophetic Conflict," 50-54, 77-78.

"Ibid., 50 .

Gen. 1:27

${ }^{14}$ Lovin, Reinhold Niebuhr, 13-15.

"Richard Crouter, Reinhold Niebuhr on Politics, Religion, and Christian Faith (Oxford: Oxford University Press, 2010), 43-44; Lovin, Reinhold Niebuhr, 15.

${ }^{16}$ Ibid., 15-17.

${ }^{17}$ Inboden, "The Prophetic Conflict," 57. 
the context of sin one must first see how Niebuhr took his conception of human nature and applied it to the global stage.

Self-interest and the will to power are axiomatic in inter-personal as well as international affairs. According to Niebuhr, the potential for sin is increased among groups compared to the individuals that constitute them. ${ }^{18}$ As Niebuhr outlined in his 1932 book Moral Man and Immoral Society, institutions created by man are more prone to self-righteousness and more likely to use power to attain their goals. As a result, "Niebuhr saw life as fundamentally a clash of interests and a quest for power." 19 On the global stage, interests of nations contend against the interests of other nations leading to inevitable conflict. For Niebuhr, the necessity for conflict results from an imbalance of power or national interests, as is the case when a nation employs imperialistic policy against another nation. It also occurs internally, when wealth, power and influence is concentrated in specific societal groups which make up a nation. Such intra-national tensions risk the potential to upset the balance of power internationally as well. In sum, the disturbance of the global power dynamic leads to a conflict which attempts to re-establish the international order. ${ }^{20}$ To Christian Realists, such action that equilibrates international harmony is justifiable even if it takes the form of war. ${ }^{21}$ To Niebuhr, such 'tipping of the scales' could only be corrected via means of aggression and power, which places Niebuhr in direct contention with the pacifist view.

To Niebuhr, pacifism sees the example of Jesus as a practical model of earthly living. Such a model necessitates inaction and the refusal to take up arms, for to do so would be in opposition to the will of God (and therefore the example of Jesus). ${ }^{22}$ In contrast to the Liberal Protestant and pacifist attitudes that lingered amongst Americans in the 1930's, Niebuhr believed that a social and political ethic cannot be derived from Jesus' example. The decree to "love thy neighbour as thyself" ${ }^{23}$ could not provide a political framework for a functioning society due to the finitude and the propensity to commit sin that is inherent to individuals and the institutions created by them. ${ }^{24}$ To Niebuhr, "Moralistic Christianity imagines that there are simple and direct methods of applying Christian ideals of love to the complexities of politics. The error of this idea lies in the fact that politics is a realm in which life is always in conflict with life and interest contends against interest." 25 Niebuhr's Christian Realism sees the law of love as an "impossible possibility" 26 and believes that resistance, even in its final form of war, was the only option when nations employ a hostile conduct. Nations are necessarily "obliged to do evil... so that good may come" because of the belligerence and egoism of other nations. ${ }^{27}$ A nation that refuses to become involved in history, regarding all violence as outside its purview, cannot hope to counter tyrannical opposition and is effectively condoning the degradation of human rights and, in the case of WWII, the mass genocide of the Jews. ${ }^{28}$ To Niebuhr, tyrants will seek invasion and the

${ }^{18}$ Crouter, Politics, Religion, and Christian Faith, 48

'Inboden, "The Prophetic Conflict," 55.

${ }^{20}$ Ibid., 55-56.

${ }^{21}$ Pavlischek, "Just War Theory," 55-57.

${ }^{22}$ Ibid.

${ }^{23}$ Matt. 22:39 KJV

${ }^{24}$ Crouter, Politics, Religion, and Christian Faith, 50-51; Pavlischek, "Just War Theory," 55;

Doenecke, "Reinhold Niebuhr and His Critics," 466; Lovin, Reinhold Niebuhr, 7-9.

${ }^{25}$ Inboden, "The Prophetic Conflict," 66.

${ }^{26}$ Reinhold Niebuhr, An Interpretation of Christian Ethics (New York: Harper, 1935), 119-20.

${ }^{27}$ Pavlischek, "Just War Theory," 57.

${ }^{28}$ Doenecke, "Reinhold Niebuhr and His Critics," 462. 
assumption of dominion upon a nation with no discrimination as to how that nation desires to interpret scripture. Georgia Harkness, a theologian that backed the pacifist stance during the inter-war period, did not agree with Niebuhr's adjudication of pacifist principles. Harkness, in her book Christian Ethics, argues against the assertion that pacifists are naïve and complacent in regards to tyranny. To Harkness, pacifists do acknowledge man's potential to wreak havoc upon other men and they understand the need to resist such evil. ${ }^{29}$ To Harkness, Realism assumes that when oppressive regimes impose upon a nation there exists two options; to acquiesce to the imposition, or to retaliate in the form of war. However, she argues that the pacifist position is not acquiescence, but rather to "deny that war [or] tyranny exhaust the possibilities." The pacifist believes that there exists (or existed) modes of negotiation, diplomacy, and mutually beneficial compromises that can quell international hostilities. ${ }^{30}$ Harkness declares that pacifists are not complacent when it comes to tyranny, but rather that they too "desire...to see aggression halted, the helpless protected, and justice established," although that desire is effected through healing and service rather than aggression and war. ${ }^{31}$ On this point, Niebuhr and Christian Realists are also of the impression that the ideals of Jesus are examples of the most noble aspirations. ${ }^{32}$ However, to Realists these ideals can only be approximated amongst the political theatre through the establishment of justice and employment of resistance towards the inherent aggression of man and his nations. George H. C. Macgregor, a professor of divinity at the University of Glasgow, believes the charges of complacency against pacifists are not warranted, because war itself can be prevented and thus those charges would not have been put forth in the first place. It is thus, in Macgregor's eyes, the lack of reconciliatory and collaborative foreign policy on the part of the non-pacifist which establishes any grounds (whether or not they are justified) to judge the pacifist. ${ }^{33}$

It should not be concluded that Christian Realism denounces all forms of love and kindness. In fact, Niebuhr's own colleagues accused him of ascribing to secularism. ${ }^{34}$ However this is not the case. Christian Realism understands that the law of love embodied by Jesus is fundamental in human life, policy, and discourse. It realizes that atrocities should be prevented, racial conflict in America should be reconciled with, and the welfare of all citizens should be strived for. ${ }^{35}$ However, what distinguishes Christian Realism with the Protestant Liberal and pacifist thought is the understanding of the inevitability of sin. Realism sees society and its subsequent changes being directly attributable to the clash of interests, and not necessarily a steady ascension towards goodness, as the Protestant Liberals purport. Realists believe that we must reconcile the law of love with the need to enact justice in the world which inevitably arises if we want to make political decisions. We still have moral imperative to strive for goodness in the world, even when the required actions might cause harm to others. ${ }^{36}$

Niebuhr had to address the question of how individuals or nations can act morally if all people (as images of God) and their institutions are equally corrupted by sin and thus will

${ }^{29}$ Georgia E. Harkness, Christian Ethics (New York: Abingdon Press, 1957), "Chapter 11: War, Peace, and International Order," http://www.religion-online.org/showbook.asp?title=802.

${ }^{30}$ Ibid.

${ }^{31}$ Ibid.

${ }^{32}$ Crouter, Politics, Religion, and Christian Faith, 52; Pavlischek, "Just War Theory," 56-57.

${ }^{33}$ Doenecke, "Reinhold Niebuhr and His Critics," 473-474.

${ }^{34}$ Lovin, Reinhold Niebuhr, xi.

${ }^{35}$ Crouter, Politics, Religion, and Christian Faith, 52; Lovin, Reinhold Niebuhr, 8.

${ }^{36}$ Ibid., 49. 
contend with other groups. ${ }^{37}$ For Niebuhr, moral decision has inherent ambiguity. We cannot attribute absolute purity and justness to our own actions, nor can we label an opposing nation's actions as exemplifying total evil. Instead, with recognition of our own shortcomings and limitations, Niebuhr advocated for "responsible action." Responsibility involved decisions between "greater and lesser evils," rather than absolutes. ${ }^{38}$ The determining factor in the assessment of what evils are greater than others comes from Niebuhr's book The Nature and Destiny of Man, which was a two-volume expansion of his Gifford Lectures of 1939, located in Edinburgh. Niebuhr contrasts an equality of sin with the inequality of guilt. Guilt as defined by Niebuhr is the "objective consequences of sin, the actual corruption of the plan of creation." For example, the casualties caused and the hardship that endures in the population after a battle would be contributors to guilt. It is also posited by Niebuhr that given the same set of sinful actions between two entities, one can be more guilty and culpable before God than the other. ${ }^{39}$ One country, for example, could be guiltier in wartime actions that result in hardship such as the destruction of property, homes, and citizens, by being the country that initiated the violence or participated in the conflict with their actions being backed by more prideful and self-glorifying motives. In Niebuhr's words, "men who are tempted by their eminence, and by the possession of undue power, become more guilty of pride and of injustice than those who lack power and position. ${ }^{\circ 0}$ Christian Realism acknowledges this and asserts that moral decisions should therefore be made to result in the "best circumstances for the most people" violate the love that all humans are called to embody. Robert Moats Miller, a professor of history in North Carolina charged Realists in America of turning a blind eye to the injustices perpetrated by the Allies themselves. To quote Miller:

"We [inflicted] wholesale death on the civilian populations of Dresden, Hamburg, and Berlin and Tokyo, Hiroshima and Nagasaki and a hundred other cities, including those of our allies; that in order to win we would shoot prisoners ... level villages, and betray friendly agents into the hands of the Gestapo." 42

However, one could view this statement as still being in tune with Christian Realism: the actions of both Axis and Allies were disastrous and at their core a sin against God. However, to American Christian Realists the importance of forestalling a nation hell-bent on world domination superseded the refrainment to murder, extricating the Allies from much of the guilt of the same wartime actions. ${ }^{43}$

To think of our actions as superior to those of others leads to idolatry. In doing so, man or the state attempt to escape the finitude that define them, and try to place themselves above God. ${ }^{44}$ Such self-glorification inevitably leads to, as previously mentioned, prideful arrogance, the imbalance of international power and inevitable conflict. An example of idolatry and the manifestation of Niebuhr's theology can be seen with the Third Reich. In 1933 Niebuhr already

${ }^{37}$ Lovin, Reinhold Niebuhr, 20.

${ }^{38}$ Ibid., xiii, 28-30.

${ }^{39}$ Reinhold Niebuhr, The Nature and Destiny of Man : A Christian Interpretation (New York:

Scribner, 1941), 236-237.

${ }^{40}$ Ibid., 237.

${ }^{41}$ Lovin, Reinhold Niebuhr, 32.

${ }^{42}$ Robert Moats Miller, How Shall They Hear without a Preacher? The Life of Ernest Fremont

Tittle (Chapel Hill: University of North Carolina Press, 1971), 456.

${ }^{43}$ Crouter, Politics, Religion, and Christian Faith, 48.

${ }^{44}$ Lovin, Reinhold Niebuhr, 16, 28. 
had apprehensions about National Socialism's hold on Germany. He described the Nazi regime as a totalitarian state, which seeks to control all sectors of the public and suppress any voices that speak out against it. ${ }^{45}$ The Nazi regime was eliminating the idea of any entity with more power than the Führer. This was being achieved through the formation of the "German Christian" Church that sought to incorporate National Socialist principles into a Christian theology, as well as the suppression, deportation and internment of all clergy that spoke against the state. "It was inevitable that the Nazis should try to deny the Christian church, because in virtually every respect its teachings are in opposition to the Nazi ideal of race supremacy and of the subordination of the individual." 46 As discussed above, when power becomes concentrated and unequally distributed within a nation it can upset the international order, and on September $1^{\text {st }}$, 1939, this became the reality as the world witnessed the Nazi invasion of Poland. In fact, during one of Niebuhr's Gifford lectures, the sounds of explosions from the German bombing of Edinburgh could be heard within the lecture hall. The destructive and idolatrous actions of Nazi Germany heard from inside the room would have presumably reinforced the topics of Niebuhr's theology that were presented that day and soon made up The Nature and Destiny of Man. ${ }^{47}$

In America, Reinhold Niebuhr represented a shift from the socially progressive Protestant Liberalism towards his own theology of Christian Realism, emphasizing the biblical understanding of a sinful human nature and the inevitability of conflict due to differing selfinterests between individuals and nations alike. Niebuhr was very influential not only in America, but across the Atlantic as well and helped the Allied peoples make sense of the idolatrous nature of the Nazi regime, as well as determine what response was morally acceptable. Niebuhr's theology swayed American attitude from anti-interventionism to active participation in the Second World War, even amongst criticism from other theologians such as Georgia Harkness, and professors like George H. C. Macgregor and Robert Moats Miller. To lastly emphasize the profound impact Niebuhr had on political discourse within the United States, one must only look to President Roosevelt's October 1941 Navy Day Address, which highlighted the deification of the state and its consequent concentration of power into the hands of Hitler. In the words of Roosevelt:

"The clergy are to be forever liquidated, silenced under penalty of the concentration camps, where even now so many fearless men are being tortured because they have placed God above Hitler. In the place of the churches of our civilization, there is to be set up an International Nazi Church-a church which will be served by orators sent out by the Nazi Government. And in the place of the Bible, the words of Mein Kampf will be imposed and enforced as Holy Writ. And in the place of the cross of Christ will be put two symbols - the swastika and the naked sword. The god of Blood and Iron will take the place of the God of Love and Mercy.",48

This alternate history, should America not "stand ready in defense of [their] Nation" was used by Roosevelt to instill in the masses a patriotic sentiment as the Navy prepared to ramp up production and distribution of equipment and supplies to America's Allies. He stresses the Nazi

\footnotetext{
${ }^{45}$ Inboden, "The Prophetic Conflict," 62.

${ }^{46}$ Ibid., 78-80.

${ }^{47}$ Lovin, Reinhold Niebuhr, xii; Inboden, "The Prophetic Conflict," 72.

${ }^{48}$ Franklin D. Roosevelt, "Address for Navy and Total Defense Day" (speech, Washington, DC, October 27, 1941), The American Presidency Project, http://www.presidency.ucsb.edu/ws/?pid=16030
} 
effort to dismantle religion, and the atrocities that they currently or might soon implement to do so. Christian Realism rings through Roosevelt's speech; through this address Roosevelt stresses the need to counter the "curse of the Hitlerism," the weight which imbalances the international balance of power. By drawing attention to Nazism and its self-perceived omnipotence, he calls for America to "[ready their] battle stations," as they prepare to fight an enemy which threatens American self-interest and the core values which established the nation; "the spirit of adventure and restlessness and individual independence which will not tolerate oppression." 
Bibliography

Crouter, Richard. Reinhold Niebuhr on Politics, Religion, and Christian Faith. Oxford: Oxford University Press, 2010.

Doenecke, Justus D. "Reinhold Niebuhr and His Critics: The Interventionist Controversy in World War II." Anglican and Episcopal History 64, no. 4 (1995): 459-81.

Harkness, Georgia E. Christian Ethics. New York: Abingdon Press, 1957.

Inboden, William C. "The Prophetic Conflict: Reinhold Niebuhr, Christian Realism, and World War II.” Diplomatic History 38, no. 1 (2014): 49-82.

Lovin, Robin W. Reinhold Niebuhr. Nashville: Abingdon Press, 2007.

Miller, Robert Moats. How Shall They Hear without a Preacher? The Life of Ernest Fremont Tittle. Chapel Hill: University of North Carolina Press, 1971.

Niebuhr, Reinhold. An Interpretation of Christian Ethics. New York: Harper, 1935. . The Nature and Destiny of Man: A Christian Interpretation. New York: Scribner, 1941.

Pavlischek, Keith. "Reinhold Niebuhr, Christian Realism, and Just War Theory A Critique." In Christianity and Power Politics Today: Christian Realism and Contemporary Political Dilemmas, edited by Eric Patterson, 53-71. New York: Palgrave Macmillan US, 2008. Roosevelt, Franklin D. "Address for Navy and Total Defense Day." Speech, Washington, DC, October 27, 1941. The American Presidency Project.

http://www.presidency.ucsb.edu/ws/?pid=16030 